\title{
PERCEIVED ORGANIZATIONAL SUPPORT DAN ORGANIZATIONAL CITIZENSHIP BEHAVIOR PADA PERAWAT RUMAH SAKIT
}

\author{
Alimatus Sahrah \\ Universitas Mercu Buana Yogyakarta \\ alimatus_sahrah@yahoo.co.id
}

\begin{abstract}
Abstrak
Upaya terhadap menciptakan kepuasan terhadap pasien merupakan hal utama untuk diwujudkan di setiap Rumah Sakit. Penelitian ini ingin melihat adanya hubungan antara Perceived Organizational Support (POS) dengan Organizational Citizenship Behavior (OCB) pada para perawat di ruang inap Rumah Sakit DK di Yogyakarta, Indonesia. Subjek penelitian ini berjumlah 72 orang perawat. Karakteristik dari subjek penelitian adalah berumur 20 tahun sampai dengan 50 tahun, dan memiliki tingkat pendidikan minimal Diploma 3. Metode untuk pengumpulan data penelitian adalah menggunakan metode skala, yaitu menggunakan Skala POS dan skala OCB, dengan reliabilitas 0,950 dan 0,905 dan daya beda item total berkisar antara 0,31 s/d 0,80 dan 0,292 s/d 0,806. Analisis data penelitian menggunakan analisis korelasi product moment dan analisis regresi ganda. Dari penelitian ini dapat disimpulkan bahwa ada hubungan antara POS dengan OCB pada para perawat rawat inap RS. Aspek POS yang menyatakan bahwa perawat merasakan adanya dukungan organisasi terhadap ide-ide karyawannya dan adanya dukungan organisasi terhadap kesejahteraan karyawannya, adalah aspek POS yang signifikan berpengaruh terhadap timbulnya Organizational Citizenship Behavior pada para perawat Rumah Sakit.
\end{abstract}

Kata Kunci: Perceived Organizational Support, Organizational Citizenship Behavior, dan perawat

\section{PERCEIVED ORGANIZATIONAL SUPPORT AND ORGANIZATIONAL CITIZENSHIP BEHAVIOR ON HOSPITAL NURSES}

\author{
Alimatus Sahrah \\ Universitas Mercu Buana Yogyakarta \\ alimatus_sahrah@yahoo.co.id
}

\begin{abstract}
Efforts to create patient satisfaction are the main things to be realized in every hospital. This study wanted to see the relationship between Perceived Organizational Support (POS) and Organizational Citizenship Behavior (OCB) in nurses in the inpatient ward of the DK Hospital in Yogyakarta, Indonesia. The subjects of this study were 72 nurses. The characteristics of the study subjects were aged 20 years to 50 years, and had a minimum education level of Diploma 3. The method for collecting data was using a scale method, that is using the POS Scale and OCB scale, with reliability 0.950 and 0.905 and different power items totaling between 0.31 to 0.80 and 0.292 to 0.806 . Analysis of research data using product moment correlation analysis and multiple regression analysis. From this study it can be concluded that there is a relationship between POS and OCB on hospital nurses. Aspects of POS that states that the nurses feel the existence of organizational support for the ideas of employees and the existence of organizational support for the welfare of its employees, is a significant aspect of POS effect on the emergence of Organizational Citizenship Behavior on the nurses Hospital
\end{abstract}


Keywords: Perceived Organizational Support, Organizational Citizenship Behavior, and nurses.

\section{PENDAHULUAN}

Kepuasan pasien adalah tujuan dari penyelenggaraan pelayanan kesehatan di suatu Rumah Sakit dan Perawat merupakan ujung tombaknya Rumah sakit dalam melakukan pelayanan kesehatan tersebut. Menurut Peraturan Mentri Pendayagunaan Aparatur Negara dan Reformasi Birokrasi Republik Indonesia Nomor 25 Tahun 2014, tugas pokok Perawat adalah melakukan kegiatan pelayanan keperawatan yang meliputi asuhan keperawatan, pengelolaan keperawatan dan pengabdian pada masyarakat (PERMEN (2014).

Seperti disebutkan oleh Nuralita \& Hadjam (2002), perawat diharapkan melayani pasien dengan ramah serta didukung oleh sikap menaruh minat dan tampilan yang baik, karena sikap tersebut akan membuat pasien dan keluarganya merasa tenang dan nyaman di rumah sakit. Hal inilah yang menjadi keprihatinan di Rumah Sakit DK karena dari hasil observasi dan wawancara selama bulan April 2015, dapat dinyatakan bahwa para perawatnya terkenal tidak ramah, pasien merasa tidak diperlakukan perawat dengan sabar, perawat suka terkesan saling melempar tanggung jawab, suka berpurapura sibuk.
Dalam upaya mewujudkan pelayanan yang prima demi kepuasan para pasien, pihak rumah sakit seharusnya tidak saja mendorong para perawat untuk melakukan tugas pokoknya saja tetapi juga harus memperhatikan tugas ekstraperannya dalam memenuhi harapan dan tuntutan pasien serta masyarakat untuk mendapat pelayanan kesehatan yang optimal. Tugas ekstra-peran (extra-role) yang dimaksud adalah perilaku di luar tugas pokok yang dilakukan secara sukarela oleh para tenaga kerja di tempat kerjanya demi kepentingan organisasinya.

Perilaku extra-role adalah perilaku yang dilakukan karyawan di luar uraian pekerjaan secara formalnya, tetapi perilaku ini sangat dihargai jika ditampilkan oleh karyawan, karena perilaku ini dapat meningkatkan efektivitas dan kelangsungan hidup organisasi (Katz dalam Purba \& Seniati, 2004). Perilaku ekstra-peran ini dapat juga disebut sebagai tindakan prososial yang melebihi deskripsi peran yang ditetapkan organisasi tersebut, dan oleh Organ dan Konovsky (1989) dinamakan sebagai Organizational Citizenship Behavior, disingkat sebagai OCB.

OCB dapat dikatakan sebagai kontribusi individu yang melebihi tuntutan peran di tempat kerjanya, tidak berkaitan 
langsung, atau tidak secara eksplisit dihubungkan dengan sistem reward, dan perilaku ini bisa meningkatkan fungsi keefektivan organisasi (Organ dkk., 2006). Contohnya meliputi bantuan terhadap teman kerja untuk meringankan beban kerja, tidak melakukan banyak berisitirahat di tempat kerja, membantu orang lain menyelesaikan tugasnya, melaksanakan tugasnya tanpa diperintah.

Menurut Podsakoff \& MacKenzie (2009), OCB yang dimiliki tenaga kerja terbukti dapat meningkatkan efektivitas kerja organisasi. Hal ini sejalan dengan apa yang disebutkan oleh Frances (dalam Muchiri, 2002) bahwa OCB merupakan perilaku yang bersifat sukarela, dan berada di luar deskripsi peran yang ditetapkan pihak organisasi, tetapi perilaku tersebut mempunyai kontribusi bagi keefektifan organisasi, dan secara langsung berhubungan dengan kepuasan kerja para karyawan.

LePine dkk. (2002) mengungkapkan beberapa karakteristik OCB, yang meliputi: (a) Perilaku bersifat sukarela dan tidak termasuk dalam uraian jabatan, (b) Perilaku yang bersifat spontan dalam arti tidak diperintah atau disarankan oleh orang lain; (c) Perilaku memiliki kontribusi terhadap keefektifan organisasi, yaitu perilaku untuk merasa bertanggung jawab atas kelangsungan organisasi; (d) Perilaku yang tidak mudah diambil dan dihargai melalui evaluasi kinerja karena perilaku tersebut tidak tercantum dalam uraian jabatan.

Dari karakteristik yang diungkapkan oleh LePine dkk. (2002), dan Organ, dkk. (2006) dapat disimpulkan bahwa ada lima dimensi yang dapat digunakan sebagai tolok ukur apakah seseorang karyawan memiliki OCB rendah atau tinggi. Lima aspek OCB tersebut adalah (1) altruism, yaitu perilaku membantu orang lain yang dilakukan secara sukarela oleh karyawan (yang dalam hal ini perawat) yang berdampak penyelesaian permasalahan organisasi menjadi lebih efektif. Misalnya perilaku membantu perawat lain tanpa ada paksaan pada tugas-tugas yang berkaitan erat dengan tugas-tugas organisasi; courtesy, adalah perilaku sukarela dalam diri setiap individu untuk mencegah timbulnya masalah dengan orang lain sehubungan dengan pekerjaannya. Perilaku ini menunjukkan adanya perilaku berbuat baik dan hormat kepada orang lain, termasuk membantu seseorang untuk mencegah terjadinya suatu permasalahan, atau membuat langkah-langkah untuk mengurangi berkembangnya suatu masalah. Misalnya perilaku meringankan problem-problem yang berkaitan dengan pekerjaan yang dihadapi orang lain, (3) sportsmanship, adalah keinginan sukarela perawat untuk mentolerir kekurangan dari kondisi ideal tanpa banyak mengeluh atau 
komplain. Perilaku sportsmanship ini menunjukkan perilaku yang lebih menekankan pada aspek-aspek positif organisasi daripada aspek-aspek negatifnya. Dalam hal ini mengindikasikan perilaku tidak senang protes, tidak mengeluh, dan tidak membesar-besarkan masalah kecil atau sepele. Sportsmanship berisi tentang pantangan-pantangan membuat isu yang merusak citra organisasi. (4) civic virtue, adalah perilaku bertanggung jawab untuk selalu berpartisipasi atau terlibat dalam kehidupan organisasinya. Misalnya berpartisipasi secara sukarela dalam mendukung kegiatan-kegiatan organisasi baik formal maupun informal; conscientiousness, adalah perilaku sukarela perawat yang melampaui persyaratan minimum peran organisasi, misalnya di bidang kehadiran, mematuhi aturan dan peraturan, mengambil istirahat, dan sebagainya.

Menurut Allen \& Rush (1998), Organizational Citizenship Behavior (OCB) merupakan kontribusi individu dalam melebihi tuntutan peran di tempat kerja. OCB ini melibatkan beberapa perilaku meliputi perilaku suka menolong orang lain, menjadi volunteer untuk tugastugas ekstra, patuh terhadap aturan-aturan dan prosedur-prosedur di tempat kerja. Perilaku ini menggambarkan nilai tambah karyawan yang merupakan salah satu bentuk perilaku prososial, yaitu perilaku sosial yang positif, konstruktif dan bermakna membantu.

$$
\text { Greenberg \& Baron (2003) }
$$
mengatakan bahwa OCB merupakan perilaku informal dimana seorang karyawan melakukan sesuatu di luar aturan formal tetapi perilaku tersebut sesuai dengan harapan perusahaan sebagai bentuk konstribusi terhadap kesejahteraan organisasi juga hal-hal yang terkait di dalamnya. Dengan kata lain OCB merupakan perilaku inisiatif dari karyawan, di mana perilaku tersebut tidak tertera dalam aturan yang telah ditetapkan dalam perusahaan.

Dari paparan terdahulu dapat disimpulkan bahwa permasalahan OCB dari para perawat menjadi sangat penting untuk peningkatan pelayanan Rumah Sakit terhadap pasiennya. Gambaran tersebut menjadi semakin nyata bila dilihat dari hasil observasi dan wawancara awal penelitian terhadap 15 orang pasien pada tanggal 1 sampai dengan 15 Mei 2016, yang diperoleh kesimpulan bahwa 10 orang pasien merasa diperlakukan tidak secara tidak ramah oleh para petugas yang merawatnya, 12 orang pasien merasa bahwa keingintahuannya terhadap penyakitnya tidak dijawab dengan baik oleh para perawat, 8 orang pasien merasa sakit hati ketika dikatakan sebagai pasien yang manja oleh perawat yang 
merawatnya. Gambaran OCB perawat yang rendah ini membuat jelas bahwa OCB dapat didefinisikan sebagai tindakan sukarela yang tidak diperuntukkan bagi kepentingan pribadi tetapi untuk kepentingan organisasi, tindakan yang tidak diakui untuk mendapatkan kompensasi, dan tindakan yang tidak diperintah secara formal. Dengan kata lain OCB merupakan kontribusi karyawan di luar uraian tugas formal, yang dilakukan secara sukarela, yang secara formal tidak diakui sebagai reward atau imbalan, dan memberikan kontribusi pada keefektifan organisasi.

Menurut Podsakoff, dkk. (dalam Garay, 2006), ada empat faktor yang mendorong munculnya OCB dalam diri karyawan yaitu karakteristik individual, karakteristik tugas, karakteristik organisasional, dan perilaku pemimpin. Karakteristik individu ini meliputi persepsi keadilan, kepuasan kerja, komitmen organisasional, karakterisitk tugas meliputi kejelasan atau ambiguitas peran, sementara karakteristik organisasional meliputi struktur organisasi, dan model kepemimpinan. Lebih lanjut dikatakan bahwa job attitudes, karakteristik tugas dan perilaku pemimpin diketemukan memiliki hubungan yang lebih kuat terhadap OCB dibandingkan penyebab lainnya.

Organ dkk. (2006) mengatakan bahwa Perceived Organizational Support
(POS) adalah salah satu faktor yang dapat mempengaruhi tinggi rendahnya OCB seseorang. Perceived Organizational Support (POS) adalah persepsi dukungan organisasi yang dirasakan seseorang tentang sejauh mana tingkat para pekerja (dalam hal ini perawat) mempercayai bahwa organisasi menilai kontribusinya dan peduli terhadap kesejahteraan dirinya (Robbins \& Judge, 2015).

\section{Perceived Organizational Support} atau biasa disingkat POS bisa diartikan sebagai dukungan organisasi yang dipersepsikan dengan keyakinan global mengenai sejauh mana organisasi menilai kontribusi, memperhatikan kesejahteraan, mendengar keluhan, memperhatikan kehidupan dan mempertimbangkan tujuan yang akan dicapai serta dapat dipercaya untuk memperlakukan karyawan dengan adil. Dukungan organisasi merupakan kepercayaan global karyawan mengenai sejauh mana organisasi mereka menilai kontribusi dan memperhatikan kehidupan karyawannya (Eisenberger dkk., 2002).

Robbins \& Judge

(2008)

berpendapat bahwa dukungan organisasional yang dirasakan adalah tingkat sampai dimana karyawan yakin organisasi mengahargai kontribusi mereka dan peduli dengan kesejahteraan mereka. Kecuali jika manajemen tidak mendukung para karyawannya, maka karyawan akan melihat tugas-tugas tersebut sebagai 
sesuatu yang tidak menyenangkan dan memperlihatkan hasil kerja yang tidak efektif untuk organisasi.

Konsep dukungan organisasional (POS) telah lama dijelaskan oleh para ilmuwan manajemen dalam literaturliteratur teori keadilan distributif. Teori keadilan distributif menyebutkan bahwa individu-individu dalam organisasi akan mengevaluasi hasil-hasil organisasi dengan memperhatikan beberapa aturan distributif berdasarkan hak menurut keadilan atau kewajaran. Sedangkan teori kewajaran (equity) mengemukakan bahwa penghargaan organisasi harus didistribusikan sesuai tingkat kontribusi individual (Cowherd \& Levine, 1992).

Rhoades \& Eisenberger (2002) berasumsi bahwa teori POS didasarkan pada teori pertukaran sosial atau social exchange teory, yaitu teori pertukaran sosial, hubungan antara karyawan dengan organisasinya. Dalam hal ini POS mengacu pada persepsi karyawan mengenai sejauhmana organisasi menilai kontribusi mereka dan peduli terhadap kesejahteraan mereka. Persepsi disini penting karena karyawan mempunyai harapan akan adanya dukungan organisasi terhadap kebutuhan mereka, sehingga dapat dijelaskan bahwa teori POS ini dibangun karena adanya harapan ini dalam diri karyawan (Eisenberger, Huntington, Hutchison dan Sowa, 1986)
Dari penelitiannya Eisenberger dkk., (1986) menyatakan bahwa para karyawan menganggap pekerjaan mereka sebagai hubungan timbal balik yang mencerminkan ketergantungan relatif yang melebihi kontrak formal dengan organisasinya, hal ini dapat diartikan bahwa karyawan dan organisasi terlibat dalam hubungan timbal balik. Karyawan melihat sejauh mana organisasi akan mengakui dan menghargai usaha mereka, mendukung kebutuhan socio-emotional mereka dan sebagai karyawan mereka akan memperlakukan organisasinya dengan baik.

Eisenberger, Huntington, Hutchison \& Sowa (1986) menjelaskan bahwa dukungan organisasi karyawan oleh perlakuan-perlakuan organisasi yang diterima, misalnya dalam pemberian honorarium, kenaikan jabatan, dan partisipasi dalam pembuatan kebijakan organisasi. Penilaian karyawan terhadap organisasi juga dilakukan dengan memperhatikan frekuensi, kesungguhan dan ketulusan organisasi dalam memberikan pernyataan perhargaan dan pengakuan terhadap hasil usaha mereka. Pemberian penghargaan atau penciptaan kondisi kerja yang menyenangkan, jika dilakukan karena kemauan organisasi sendiri akan mempunyai pengaruh yang lebih besar terhadap dukungan organisasi dibandingkan dengan jika diberikan karena tekanan dari luar misalnya tekanan dari 
serikat pekerja atau daripada adanya peraturan perundangan (Rhoades \& Eisenberger, 2002).

POS adalah tingkat kepercayaan karyawan atas penghargaan yang diberikan oleh organisasi terhadap kontribusi yang telah diberikannya, dan perhatian organisasi pada kesejahteraan karyawannya (Eisenberger dkk. (dalam Coyle dkk., 2004). Tingkat kepercayaan karyawan terhadap dukungan organisasi ini akan dipengaruhi oleh evaluasi mereka atas pengalaman dan pengamatannya terhadap bagaimana organisasi memperlakukan karyawan-karyawannya secara umum.

Menurut Rhoades \& Eisenberger (2002), POS memiliki aspek-aspek yang berasal dari definisinya tersebut, yaitu penghargaan pada kontribusi karyawan dan perhatian atau kepedulian organisasi terhadap kesejahteraan karyawannya. Selanjutnya untuk mengukur POS, Allen \& Brady (1997) mengemukakan ada 3 aspek POS, yaitu : (1) Sikap organisasi terhadap ide-ide karyawan. Bila organisasi dinilai oleh karyawan, dapat melihat atau menghargai ide-ide karyawannya, maka POS menjadi positif. Sebaliknya, POS akan menjadi negatif bila perusahaan selalu menolak ide dari karyawan dan segala sesuatu merupakan keputusan dari manajemen tertinggi. (2) Sikap organisasi terhadap karyawan yang mengalami masalah. Bila organisasi dinilai tidak memperlihatkan usaha untuk membantu karyawan yang sedang terlibat masalah. Hal ini akan menyebabkan karyawan melihat tidak ada dukungan yang diberikan organisasi terhadap karyawan yang bersangkutan. (3) Sikap organisasi terhadap kesejahteraan dan kesehatan karyawan. POS disebut tinggi, jika karyawan melihat bahwa organisasi memberikan dukungan agar setiap orang dapat bekerja secara optimal demi tercapainya tujuan bersama.

Konsep POS ini menekankan fakta bahwa sejauh mana organisasi memperhatikan kesejahteraan dan masa depan para karyawannya Jika karyawan merasa didukung dan dihormati oleh organisasinya dan mereka merasa bahwa organisasi tersebut menangani kesejahteraan dan masa depan mereka, maka para karyawan tidak segan juga melakukan upaya untuk mencapai tujuan organisasinya (Eisenberger dkk., 1986). Karyawan yang mengalami banyak dukungan organisasi yang dirasakan akan merasa bahwa mereka harus mengembangkan perilaku yang sesuai sebagai tanggapan terhadap organisasi terkait mereka untuk bertindak sejalan dengan tujuan organisasi mereka. Keyakinan karyawan yang tinggi tehadap dukungan organisasional (Perceived Organizational Support /POS) kepada 
kualitas kehidupan kerja perawat akan menimbulkan rasa ingin melakukan hal yang sama terhadap organisasinya (Eisenberger dkk., 1997). Kepedulian karyawan terhadap organisasi dan kepedulian karyawan terhadap pencapaian tujuan organisasi tersebut dapat ditunjukkan dengan menampilkan OCB karyawan, yaitu adanya sikap positif dan perilaku kerja yang sesuai dengan apa yang diharapkan oleh organisasi, walaupun perilaku tersebut tidak tercantum dalam uraian tugas, dan kemungkinan tidak akan mendapatkan reward dari organisasi.

Berdasarkan uraian terdahulu itulah, maka penelitian ini ingin membuktikan adanya hubungan antara Perceived Organizational Support terhadap Organizational Citizenship Behavior perawat ruang rawat inap RS DK di Yogyakarta.

\section{METODE}

Penelitian ini menggunakan dua variabel penelitian, yaitu variabel POS sebagai variabel independen, dan OCB sebagai variabel dependen. Kedua variabel tersebut diukur berdasarkan skala POS dan skala OCB. Skala POS adalah skala dimodivikasi dari Skala Perceived Organizational Support yang dikembangkan oleh Eisenberger dkk.,(1990).
Dari hasil ujicoba Skala POS memiliki 28 aitem dengan koefisien itemtotal yang telah dikoreksi berkisar antara 0,31 s/d 0,80 dan diperoleh koefisien reliabilitas alpha cronbach sebesar 0,95,

Adapun untuk skala OCB memiliki 33 aitem dengan koefisien item-total yang telah dikoreksi berkisar antara 0,292 s/d 0,806 dan diperoleh koefisien reliabilitas alpha cronbach sebesar 0,905 .

Subjek penelitian ini berjumlah 72 orang perawat rawat inap di Rumah Sakit DK di Yogyakarta. Subjek penelitian ini terdiri dari 5 orang perawat pria dan 67 orang perawat wanita, dengan karakteristik memiliki pendidikan minimum Diploma 3 dan berumur 20-50tahun.

Analisis data penelitian menggunakan analisis korelasi product moment dari Carl Pearson untuk menganalisis adanya hubungan antara POS dan OCB, sedangkan analisis regresi ganda dipergunakan untuk melihat adanya sumbangan efektif yang paling tinggi diantara aspek-aspek POS terhadap OCB.

\section{HASIL DAN PEMBAHASAN}

Tabel 1 menunjukkan diskripsi statistik yang terdiri dari data (1) $\mathrm{N}$ adalah Jumlah subjek penelitian; (2) Min adalah Angka atau Skore minimum yang diperoleh, (3) Max adalah Angka atau Skor maksimum yang diperoleh, (4) Mean 
adalah rerata; dan (5) SD adalah Standart

Deviasi.

Tabel 1. Diskripsi Statistik Variabel Penelitian

\begin{tabular}{lrrrrr}
\hline & N & Min & Max & \multicolumn{1}{c}{ Mean } & \multicolumn{1}{l}{ SD } \\
\hline \multicolumn{2}{l}{ DATA EMPERIK } \\
POS & 72 & & & & \\
OCB & 72 & 86 & 109 & 85,37 & 5,47 \\
\multicolumn{4}{l}{ DATA HIPOTETIK } \\
POS & 72 & 28 & 112 & 101,68 & 7,80 \\
\hline OCB & 72 & 33 & 132 & 82.5 & 18.7 \\
\hline
\end{tabular}

Pada tabel 1 dapat dilihat terhadap deskripsi statistik dari variabel demografi (umur dan sexe atau jenis kelamin) dan pada tabel 2 dipaparkan tentang kategorisasi data emperis dari variabel penelitian POS dan OCB. Pada tabel 2, dapat dibuktikan bahwa sebagian besar subjek telah merasakan adanya Dukungan Organisasi atau POS. Pada tabel 2 dicatat bahwa $34.7 \%$ subjek penelitian ada pada kategori tinggi, dan bahkan $22.2 \%$ subjek dapat dikategorikan sebagai sangat tinggi, tetapi masih ada perawat yang merasakan bahwa Dukungan Organisasi hanya dapat dikategorikan sedang saja, yaitu sebanyak $25 \%$, dan bahkan ada yang mengkategorikan POS yang mereka terima dari organisasi masih dalam kategori rendah yaitu $18 \%$ dari subjek penelitian.

Tabel 2. Kategorisasi Variabel POS \& OCB

\begin{tabular}{lcccc}
\hline Katagori & Rendah & Sedang & Tinggi & Sangat Tinggi \\
Pedoman & $<\mathrm{Q} 1$ & $\mathrm{Q} 1-\mathrm{Q} 2$ & $\mathrm{Q} 2-\mathrm{Q} 3$ & $>\mathrm{Q} 3$ \\
\hline $\mathbf{P O S}$ & & & & \\
Standart & $<82$ & $82-84$ & $84-86$ & $>86$ \\
Frekuensi & 13 & 18 & 25 & 16 \\
Persentase & $18 \%$ & $25 \%$ & $34.7 \%$ & $22.2 \%$ \\
$\mathbf{\text { OCB }}$ & & & & \\
Standart & $<86$ & $86-101$ & $101-105$ & $>105$ \\
Frekuensi & 0 & 35 & 20 & 17 \\
Persentase & 0 & $48.6 \%$ & $27.7 \%$ & $23 . \%$ \\
\hline
\end{tabular}

Hal ini dapat disimpulkan bahwa organisasi dalam hal ini Rumah Sakit masih memiliki pekerjaan rumah yaitu untuk mengusahakan bahwa para perawat merasakan dapat merasakan adanya dukungan organisasi (Rumah Sakit) baik yang menunjukkan dukungannya terhadap ide-ide dari perawat, ikut membantu menyelesaikan permasalahanpermasalahan yang dirasakan perawat, dan 
membuat kesejahteraan perawat menjadi lebih meningkat lagi.

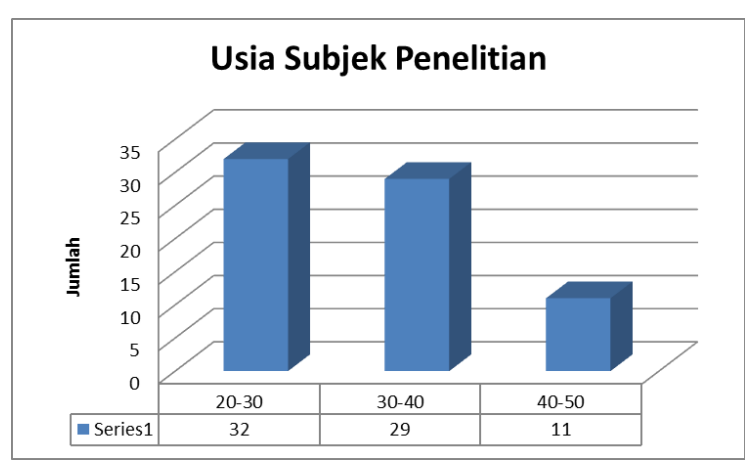

Gambar 1. Distribusi Usia Subjek Penelitian

Jika dilihat dari penyebaran usia pada subjek penelitian ini, dapat dicatat bahwa sebagian besar subjek penelitian memiliki usia yang relatif masih muda, yaitu berumur sekitar 20 tahun sampai dengan 30 tahun $(32=44 \%)$; dan berumur sekitar 30 tahun sampai dengan 40 tahun $(25=40 \%)$, sedangkan subjek yang relatif tua, yaitu berumur sekitar 40 tahun sampai dengan 50 tahun $(11=15.2 \%)$ dicatat lebih sedikit (lihat Gambar 1). Hal ini dapat diartikan bahwa subjek yang relatif muda cenderung lebih ingin mendapatkan POS daripada subjek yang sudah relatif berumur, yang biasanya relatif lebih dapat menerima situasi keadaan sehingga dapat merasakan POS.

$$
\text { Jika dilihat secara emperis }
$$
didapatkan bukti pada tabel 2, bahwa memang subjek sebagian besar telah mampu menunjukkan perilaku ekstra peran (OCB), $48.7 \%$ kategori sedang, $27.7 \%$ dikategorikan tinggi, 23\% dikategorikan sangat tinggi (0\% untuk kategorisasi OCB rendah). Hal ini dapat disimpulkan bahwa subjek penelitian sudah menunjukkan OCB, walau masih perlu ditingkatkan karena sebagian besar masih berada pada kategori sedang.

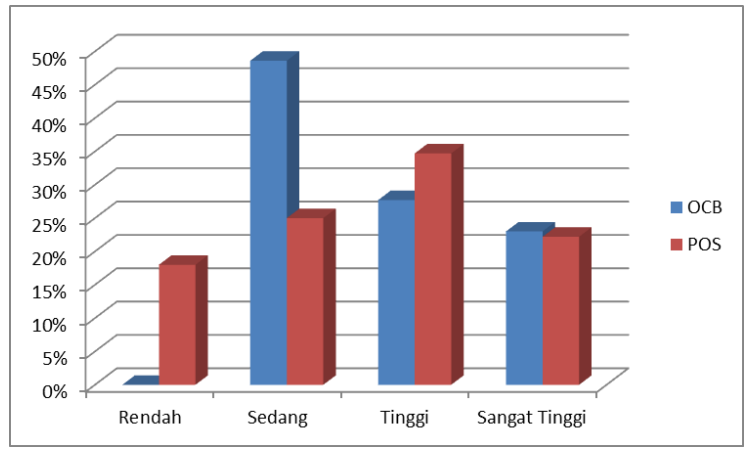

Gambar 2. Prosentase OCB \& POS pada Setiap Katagorisasi

Adapun perbandingan besaran prosentase POS dan OCB untuk setiap kategorinya dapat dilihat ada Gambar 2, bahwa secara umum para perawat telah melihat adanya dukungan organisasi pada para karyawannya, dan perilaku kewargaan organisasi (OCB) perawat dapat dinyatakan baik karena tidak ada yang memiliki perilaku pada kategori rendah. Untuk itu maka dapat diduga memiliki korelasi yang kuat diantara keduanya.

Untuk menguji hipotesis penelitian ini yang mengatakan adanya hubungan yang positif dan signifikan antara Perceived Organizational Support dengan Organizational Citizenship Behavior, maka perlu diteliti dulu uji normalitas dari ke dua variabel penelitian tersebut. 
Tabel 3. Uji Normalitas POS \& OCB

\begin{tabular}{llll}
\hline & \multicolumn{3}{c}{ Kolmogorov-Smirnov Test } \\
\cline { 2 - 4 } & Value & $\mathrm{p}$ & Keterangan \\
\hline POS & 1,286 & .073 & Normal \\
OCB &, 844 &, 474 & Normal \\
\hline
\end{tabular}

Hal ini dapat ditunjukkan pada tabel ditunjukkan pada tabel 3 , nilai uji 3 bahwa penyebaran nilai variabel Kolmogorov-Smirnov variabel-variabel Perceived Organizational Support dan tersebut adalah 1.286 ( $>0.05)$ untuk variabel Organizational Citizenship variabel POS, dan ,844 (p>0,05) untuk Behavior, adalah normal seperi yang variabel POS.

Tabel 4. Interkorelasi Variabel-Variabel Penelitian ( $\mathrm{N}=72)$

\begin{tabular}{lrrrr}
\hline & Usia & Sexe & \multicolumn{1}{c}{ POS } & \multicolumn{1}{c}{ OCB } \\
\hline Usia & -- &, 133 &,- 078 &,- 044 \\
Sexe & & -- &, 178 &, 080 \\
POS & & & -- &, $512^{* * *}$ \\
OCB & & & -- \\
\hline **. Koefisien korelasi $\mathrm{p}<.01 ;$ & &
\end{tabular}

Hasil perhitungan interkorelasi antara variabel - variabel penelitian POS dan OCB beserta variabel demografi: sexe dan usia dapat dilihat pada tabel 4. Dari tabel 4 ini dapat disimpulkan bahwa hipotesis penelitian dapat dinyatakan terbukti. Hal ini dapat dinyatakan bahwa ada hubungan yang sangat signifikan $(\mathrm{p}<0,01)$ antara POS dengan OCB, yang ditunjukkan dengan besaran koefisien korelasi 0,512. Hal ini berarti bahwa semakin perawat merasakan adanya dukungan organisasinya (POS) tinggi, maka perilaku kewargaan atau perilaku peran ekstra (OCB) perawat akan terlihat tinggi pula. Demikian juga pada perawat yang sedikit merasakan adanya dukungan organisasi terhadap dirinya, maka perawat menjadi kurang menunjukkan perilaku OCB nya. Sumbangan POS terhadap OCB perawat adalah sebesar 26,2\%, artinya perilaku OCB perawat dapat terbentuk merupakan hasil konstribusi POS sebanyak $26,2 \%$, sedangkan $72,7 \%$ ditentukan oleh variabel-variabel lainnya, misalnya karakteristik individu, karakteristik tugas dan karakteristik pemimpinnya.

Hasil penelitian ini sejalan dengan penelitian Shore dan Wayne (1993) yang menemukan bahwa persepsi terhadap dukungan organisasi (POS) merupakan faktor untuk memprediksi OCB. Karyawan yang merasa bahwa mereka didukung oleh organisasi akan memberi timbal baliknya (feedback) dan akan menurunkan ketidakseimbangan dalam hubungan 
tersebut dengan menunjukkan perilaku Organizational Citizenship Behaviornya.

Hubungan POS dan OCB para perawat ini dapat dimengerti karena dari penelitian Sahrah (2012) ditemukan bahwa kepuasan kerja berpengaruh sangat signifikan terhadap Organizational Citizenship Behavior para perawat. Hal ini diartikan bahwa ketika perawat merasakan bahwa apa yang diharapkan telah terpenuhi oleh organisasi maka dirinya akan lebih menunjukkan perilaku ekstra-perannya.

Menurut Han, dkk. (2012) Persepsi karyawan atas dukungan yang diberikan oleh organisasi (POS) menjadi hal yang cukup penting untuk membentuk tingkat kepercayaan karyawan terhadap organisasinya, sehingga organisasi diharapkan tetap selalu memberikan dukungan dan peduli terhadap karyawannya. Adanya persepsi karyawan baik perspektif dari dukungan organisasional (Perceived Organizational Support/POS) buruk atau baik yang dirasakan karyawan akan menimbulkan rasa ikatan emosional positif pada organisasi, sehingga akan merasa memiliki kewajiban untuk membayarnya. Perceived organizational support menjadi prediktor OCB yang berhubungan positif dengan prestasi. Pada saat karyawan merasa didukung oleh organisasinya maka mereka akan memberikan umpan baliknya (feed back) seperti memberikan lebih (menunjukkan perilaku lebih) untuk organisasinya (Shore \& Wayne, 1993).

Hasil penelitian ini sesuai dengan hasil penelitian yang dilakukan oleh Rich dkk., (2010), bahwa Percieve organizational support berpengaruh signifikan terhadap organizational citizenship behavior. Dari penelitiannya Pradesa, dkk. (2013) juga menyimpulkan bahwa ada hubungan Percieve Organizational Support dengan perilaku positif bekerja. Menurut Kahn (1990) rasa aman secara psikologis melibatkan rasa mampu untuk menunjukkan dan melibatkan diri pada pekerjaan tanpa konsekuensi negatif. Salah satu aspek penting rasa aman berasal dari perhatian dan dukungan yang ditunjukkan oleh organisasi.

Apabila ditelaah lebih lanjut dapat dianalisis tentang seberapa besar sumbangan efektif dari masing-masing aspek dari POS dalam memprediksi OCB perawat. Dalam hal ini adalah penting guna untuk menunjukkan aspek mana yang paling berpengaruh, dan aspek mana yang kurang berpengaruh. Dengan dapat disimpulkannya aspek yang memiliki sumbangan yang besar terhadap OCB perawat, maka Rumah Sakit dapat memfokuskan strateginya untuk mengarahkan kegiatannya ke arah aspek tersebut guna mendapatkan penilaian positif dari persepsi perawat terhadap 
adanya dukungan organisasi yang keseluruhan.

diperuntukkan kepada karyawannya secara

Tabel 5. Ringkasan Analisis Regresi Tiga Aspek POS terhadap OCB

\begin{tabular}{cccc}
\hline $\mathbf{R}$ & $\mathbf{R}$ Square & $\begin{array}{c}\text { Adjusted } \\
\text { R Square }\end{array}$ & Std. Error of the Estimate \\
\hline, $664^{\mathrm{a}}$ &, 440 &, 416 & 5,962 \\
\hline . Predictors: (Constant), pos3, pos2, pos1 &
\end{tabular}

Dari hasil perhitungan statistik terhadap kesejahteraan dan kesehatan dengan teknik analisis regresi dengan karyawan, (lihat tabel 5), dapat kriterium $\mathrm{OCB}$, dan tiga prediktor yang disimpulkan bahwa besaran koefisien merupakan aspek dari POS, yaitu pos1 adalah sikap organisasi terhadap ide-ide karyawan; pos2 adalah sikap organisasi terhadap karyawan yang mengalami regresinya sebesar 0,664 , dan dapat dinyatakan signifikan $(\mathrm{p}<0,01)$ pada ringkasan perhitungan ANOVA dalam tabel 6.

masalah, dan pos3 adalah sikap organisasi

Tabel 6. Ringkasan ANOVA Tiga Aspek POS terhadap OCB

\begin{tabular}{cccccc}
\hline Model-1 & Sum of Squares & df & MeanSquare & F & p \\
\hline Regression & 1902 & 3 & 634 & 17,8 & $<, 01$ \\
Residual & 2417 & 68 & 35,5 & & \\
Total & 4319 & 71 & & & \\
\hline
\end{tabular}

Jika dilihat lebih lanjut sumbangan dari ketiga aspek POS, yaitu POS1 adalah sikap organisasi terhadap ide-ide karyawan; POS2 adalah sikap organisasi karyawan yang mengalami masalah; POS3 adalah sikap organisasi terhadap kesejahteraan dan kesehatan karyawan, maka sumbangan ke tiga aspek POS tersebut dapat dilihat pada tabel 7 .

Tabel 7. Sumbangan Tiga Aspek POS terhadap Variabel OCB

\begin{tabular}{lccc}
\hline & POS1 & POS2 & POS3 \\
\hline Koefisien R &, $397 * *$ &, 042 &, $454 * *$ \\
R Kuadrat & 0.157 & 0.001 & 0.206 \\
Persentase & $15.7 \%$ & $0.18 \%$ & $20.61 \%$ \\
\hline \multicolumn{4}{c}{ **. Koefisien Regresi p<.01; } \\
POS1:Sikap organisasi terhadap ide-ide karyawan; \\
POS2:Sikap organisasi karyawan yang mengalami masalah; POS3:Sikap organisasi terhadap \\
kesejahteraan dan kesehatan karyawan.
\end{tabular}

Pada tabel 7 dapat disimpulkan bahwa koefisien regresi POS1 terhadap
OCB sebesar ,397 $(\mathrm{p}<0,01)$, koefisien regresi POS2 terhadap OCB sebesar ,042 
( $>0,05)$, koefisien regresi POS3 terhadap OCB sebesar ,454 $(\mathrm{p}<0,01)$. Adapun sumbangan aspek POS1, POS2, POS3 secara berturut-turut terhadap OCB adalah 15,7\%; 0.18\%; dan 20.61\% (lihat Gambar $3)$.

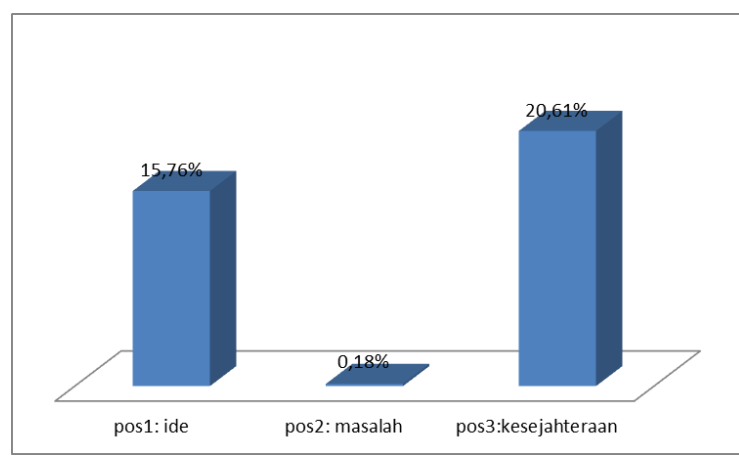

Gambar 3. Sumbangan Setiap Aspek POS terhadap OCB

Dengan demikian maka dapat disimpulkan bahwa (1) aspek POS3 adalah aspek yang paling besar pengaruhnya terhadap $\mathrm{OCB}$, dibandingkan dengan dua aspek POS lainnya; (2) dari ketiga aspek POS terdapat dua aspek yang berpengaruh secara signifikan terhadap OCB, yaitu aspek POS1, dan aspek POS3, sedangkan POS2 dinyatakan tidak mempengaruhi OCB secara signifikan.

Lebih lanjut dari tabel 7, dapat diartikan bahwa (1) Sikap organisasi terhadap kesejahteraan dan kesehatan dinilai karyawan merupakan hal yang paling besar berpengaruh terhadap adanya tindakan OCB dari para karyawannya daripada sikap organisasi terhadap ide-ide dan sikap organisasi terhadap permasalahan-permasalahan karyawan; (2) sikap organisasi terhadap permasalahanpermasalahan yang dialami karyawan selama bertugas dinilai tidak berpengaruh secara signifikan terhadap adanya tindakan OCB; (3) Sikap organisasi terhadap kesejahteraan dan kesehatan karyawan, dan sikap organisasi terhadap ide-ide yang diberikan karyawan terhadap organisasi adalah faktor yang berpengaruh terhadap timbulnya OCB pada karyawan.

\section{KESIMPULAN DAN SARAN}

Kesimpulan penelitian ini adalah: (1) hipotesis penelitian diterima, sehingga dapat dinyatakan bahwa ada hubungan yang positif dan signifikan antara POS dan OCB para perawat. (2) OCB dari para perawat masih perlu ditingkatkan, mengingat katagorisasi OCB perawat pada penelitian ini termasuk dalam kategori sedang, (3) Sikap organisasi terhadap kesejahteraan dan kesehatan dinilai karyawan merupakan hal yang paling besar berpengaruh terhadap adanya tindakan OCB dari para karyawannya daripada sikap organisasi terhadap ide-ide dan sikap organisasi terhadap permasalahanpermasalahan yang dialami para perawat; (3) sikap organisasi terhadap permasalahan-permasalahan yang dialami para perawat dinilai oleh para perawat tidak berpengaruh secara signifikan terhadap adanya tindakan OCB dirinya. 
Saran yang direkomendasikan terhadap peneliti selanjutnya adalah peneliti selanjutnya diharapkan untuk mengikutsertakan variabel lain yang berpengaruh terhadap OCB di samping POS, karena konstribusi POS dalam memprediksi timbulnya OCB hanya $26,2 \%$, sedangkan $72,7 \%$ ditentukan oleh variabel-variabel yang tidak diteliti dalam penelitian ini.

Terhadap pihak Rumah Sakit, peneliti menyarankan agar strategi kebijakan terhadap sumber daya manusia memperhatikan bagaimana dukungan organisasi (POS) dapat betul-betul terasakan oleh para karyawan (dalam hal ini perawat) karena meskipun adanya organisasi telah membuat kebijakankebijakan yang berpihak pada karyawan tetapi tidak tersosialisasi atau tidak terasakan oleh karyawan maka tidak akan menyebabkan adanya perilaku OCB. Lebih lanjut dari penelitian ini menyarankan bahwa pihak Rumah Sakit diharapkan lebih menitik beratkan kebijakannya kepada pemenuhan kesejahteraan dan kesehatan karyawan dari pada perhatian terhadap penerimaan akan ide-ide karyawan, dan perhatian organisasi terhadap permasalahan-permasalahan yang dihadapi karyawan.

\section{DAFTAR PUSTAKA}

Allen, M. W., \& Brady, R. M. (1997).
Total quality management, organizational commitment, perceived commitment, perceived organizational support, and intraorganizational communication. Management Communication Quarterly,10(3),316-341.

Allen, T.D. \& Rush, M.C. (1998), The effects of organizational citizenship behavior on performance judgments: a field study and a laboratory experiment. Journal of Applied Psychology, Apr;83(2):247-60.

Cowherd, D.M., \& Levine, D.I. (1992). Product quality and pay equity between lower-level employees and top management: An investigation of distributive justice theory. Administrative Science Quarterly, 37, 302-320

Coyle, J., Saphiro, Shore, L., Taylor, S., \& Tetrick, L. (2004). The employment relationship: Examining psychological and contextual perspectives. Oxford : Oxford University Press.

Eisenberger, R., Cummings, J., Armeli, S., \& Lynch, P. (1997). Perceived Organizational support, discretionary treatment, and job satisfaction. Journal of Applied Psychology, 82, 812-820.

Eisenberger, R., Fasolo, P.M., \& DavisLaMastro, V. (1990). Effects of perceived organizational support on employee diligence, innovation, and commitment. Journal of Applied Psychology, 53, 51-59

Eisenberger, R., Stinglhamber, F., Vandenberghe, C., Sucharski, I.L., \& Rhoades, L. (2002). Perceived supervisor support: contributions to perceived organizational support and employee retention. Journal of Applied Psychology. 20(87), 565- 
573.

Eisenberger, R; Huntington, R.; Hutchison, S.; \& Sowa, D. (1986). Perceived organizational Support. Journal Apllied Psychology, 71, 3, $500-$ 507. Diunduh 17 mei 2017. http://classweb.uh.edu/eisenberger/

wp-

content/uploads/sites/21/2015/04/22

_Perceived_Organizational_Support. pdf

Garay, H.D.V, (2006). Kinerja Extra-Role dan Kebijakan Kompensasi, Sinergi Kajian Bisnis dan Manajemen, Vol.8, No.1, 33-42

Greenberg, J. \& Baron, R.A. (2003), Behavior in Organizations Understanding and Managing the Human Side of Work. New Jersey: Prentice-HallInternational

Han, T.S., Nugroho, A., Kartika, E.W., \& Kaihatu, T.S. (2012). Komitmen Afektif dalam Organisasi yang Dipengaruhi Perceived Organizational Support dan Kepuasan Kerja. Jurnal Manajemen \& Kewirausahaan, 2 (14). h: 109117.

Kahn, W. A. (1990). Psychological Conditions of Personal Engagement and Disengagement at Work, Academy of Management Journal; Dec 1990; 33, 4; ProQuest pg. 692

LePine, J.A., Erez, A., \& Johnson, D.E. (2002). The nature and dimensionality of organizational citizenship behavior: A critical review and meta-analysis. Journal of Applied Psychology, 87, 52-65.

Muchiri, M.K. (2002). An Inquiry into The Effects of Transformational and Transaction al Leadership Behaviors on The Subordinates Organizational Citizenship Behaviors and
Organizational Workshop. Malang: Jurnal Psikodinamik Vol. 4 No.1 Januari 2002

Nuralita, A. \& Hadjam, M. N. R. (2002). Kecemasan Pasien Rawat Inap ditinjau dari Persepsi tentang Pelayanan Keperawatan di Rumah Sakit. Anima, Indonesian Psychological Journal, 172. 150 160

Organ, D. W., Podsakoff, P. M., \& MacKenzie, S. B. (2006). Organizational citizenship behavior: Its nature, antecedents, and consequences. USA: Sage Publications, Inc.

Organ, D.W. \& Konovsky, M. (1989). Cognitive Versus Affective Determinants of Organizational Citizenship Behavior. Journal of Applied Pschology. Vol. 74, No. 1, $157-164$

PERMEN (2014). Peraturan menteri pendayagunaan aparatur negara dan reformasi birokrasi republik indonesia nomor 25 tahun 2014, tentang jabatan fungsional perawat dan angka kreditnya

Podsakoff, P. M. \& MacKenzie , S. B. (2009). Impact of Organizational Citizenship Behavior on Organizational Performance: A Review and Suggestion for Future Research. Pages 133-151 | Published online: 13 Nov 2009. http://www.tandfonline.com/doi/abs/ 10.1207/s15327043hup1002_5

Pradesa H.A., Margono S, Djumahir, Mintarti R. (2013). The Relationships of Perceived Organizational Support (POS) With Positive Work Behavior: Mediating Role of Job Satisfaction, Affective Commitment, and Felt Obligation, IOSR Journal of Business and 
Management (IOSR-JBM) Volume 13, Issue 3 (Sep. - Oct. 2013), PP 23-34

Purba, D. E. \& Seniati, A.N.L. (2004). Pengaruh Kepribadian dan Komitmen Organisasi Terhadap Organizational Citizenzhip Behavior. Sosial Humaniora, Vol. 8 No. 3 : 105-111.

Rhoades, L \& Eisenberger, R. (2002). Perceived organizational support : a review of literature. Journal of Applied Psychology. 4(87), 698 714.

Rich B.L, Jeffrey A. L., Eean R.C. (2010). Ob Engagement: Antecedents And Effects On Job Performance, Academy of Management Journal , Vol. 53, No. 3, 617-635.

Robbins, P. S. \& Judge, T.A. (2008). Perilaku Organisasi. Buku 1. Jakarta: Salemba Empat.
Robbins, P. S. \& Judge, T. A. (2015). Organizational behavior. New Jersey: Pearson Education

Sahrah, A. (2012) Organizational Citizenship Behavior ditinjau kepuasan kerja dan jenis kelamin para perawat rumah sakit. Diunduh 24 januari 2016. http://fpsi.mercubuanayogya.ac.id/wpcontent/uploads/2012/06/alin_kepua san-kerja.pdf

Shore, L.M. \& Wayne, S.J. (1993) Commitment and employee behavior: comparison of affective commitment and continuance commitment with perceived organizational support. Journal of Applied Psychology, 78 (5), 774780. DOI. $10 . \quad 1037 / 0021-$ 9010.78.5.7 